\author{
ACTA MYCOLOGICA \\ Vol. 47 (1): 35-48 \\ 2012
}

\title{
Fusaria and other fungi taxa associated with rhizosphere and rhizoplane of lentil and sesame at different growth stages
}

\author{
SOBHY I. I. ABDEL-HAFEZ, MADY A. ISMAIL*, NEMMAT A. HUSSEIN \\ and NIVIEN A. ABDEL-HAMEED
}

Department of Botany, Faculty of Science, Assiut University, Egypt

*corresponding author: madyismail@yahoo.com

Abdel-Hafez S.I.I., Ismail M.A., Hussein N.A., Abdel-Hameed N.A.: Fusaria and other fungi taxa associated with rhizosphere and rhizoplane of lentil and sesame at different growth stages. Acta Mycol. 47 (1): 35-48, 2012.

Density and diversity of Fusarium species and other fungi associated with rhizosphere and rhizoplane of lentil and sesame plants at three different growth stages were investigated. Sixteen species of Fusarium were isolated from rhizosphere (13 species) and rhizoplane (11) of both plants studied. In lentil, 11 species were recorded from its rhizosphere (9 species) and rhizoplane (8). Fusarium species associated with lentil rhizoplane gave highest number of propagules at the first stage of plant growth while the ones of Fusarium associated with the rhizosphere produced the highest number at the second stage of growth. F. solani was the most common in the three growth stages. In addition, of two growth stages, F. culmorum and $F$. tricinctum were isolated from the rhizosphere while $F$. nygamai and $F$. verticillioides from the rhizoplane. The other species were recorded from only one growth stage of lentil plant. In sesame plants, rhizosphere yielded nine Fusarium species while rhizoplane gave only six from the three stages investigated. Stage I of sesame rhizosphere possessed the highest colony forming units of Fusarium. As the case for lentil, F. solani was the most common species in sesame rhizospere and rhizoplane. F. verticillioides and $F$. nygamai (in three different growth stages) followed by $F$. oxysporum and F. tricinctum (in two growth stages) were recorded using the dilution-plate and/or soil-plate methods from sesame rhizosphere soils. Rhizoplane Fusarium species of sesame plants were isolated at the three different growth stages with almost equal number of colony forming units. F. poae came after $F$. solani in its frequency since it was recovered from two growth stages. Several of the isolated species are well-known as pathogens to many cultivated plants. To the best of our knowledge, three species are recorded here for the first time in Egypt from the rhizosphere (F. acutatum), rhizoplane of sesame plants (F. longipes) and from rhizosphere of both lentil and sesame and rhizoplane of lentil (F. nygamai).

Key words: Fusarium, rhizosphere fungi, rhizoplane fungi, Lens culinaris, Sesamum indicum, growth stages 


\section{INTRODUCTION}

The terms rhizosphere and rhizoplane are now widely used by microbial ecologists and pathologists. Because of the widespread interest in the parasitic fungi attacking roots, numerous investigations have been made to characterize the fungus flora of root surface (Katznelson et al. 1948; Davey, Papavizas 1960; Srivastava, Mishra 1971; Abdel-Fattah et al. 1977; El-Hissy et al. 1980; Foster 1986; Campbell, Neher 1996; Mandeel 2002). Successful manipulation of rhizosphere and rhizoplane microorganisms to enhance biological disease control depends on knowledge of their ecological associations (Schroth, Hancock 1981; Mandeel, Baker 1991).

Several Fusarium species such as F. oxysporum, F. verticillioides, F. solani, F. acuminatum Ellis \& Everhart and F. equiseti (Corda) Saccardo, F. semitectum, F. poae, F. sambucinum, F. dimerum Penzig were recovered in different localities in Egypt from the rhizosphere and rhizoplane of cotton seedlings (Abdel-Hafez 1974; Abdel-Kader et al. 1978), rhizoplane of broad-bean (Abdel-Fattah et al. 1977), rhizosphere of five plants namely, Helianthus annuus L., Chrysanthemum coronarium L., Nigella sativa L., Datura innoxia Mill. and Hyoscymaus muticus L. (El-Hissy et al. 1980), rhizoplane of healthy and damped-off cotton, pea, tomato, maize and wheat seedlings (Moubasher et al. 1984), rhizosphere and rhizoplane of wheat plants (Abdel-Hafez et al. 1990; Abdel-Hafez et al. 2000), of sugarcane plants (Abdel-Hafez et al. 1995), of fababean, melochia, sesame and soyabean (Hasan 2002), of some cultivated plants in newly reclaimed areas (Al-Khateeb 2004).

Lentil (protein-rich) and sesame (oilseed and food) are of the most important crops not only in Egypt but also in many other parts of the world (Bhatty 1988). However, In Egypt the areas under lentil and sesame cultivation tend to decrease due to the high infection levels by fungal diseases. Fungal diseases cause severe damage to roots, stems, leaves and pods of both lentil (Taylor et al. 2007) and sesame plants (Kolte 1985) of which root-rot and vascular wilt (caused by Fusarium oxysporum) are among the most important in Egypt in sesame (Hamdi et al. 1991) and lentil (Morsy 2005).

Since no reports are available on Fusarium species that might affect roots at different growth stages of lentil and sesame in Egypt, the present work aimed to survey Fusarium species and other fungal taxa from the rhizosphere and rhizoplane of lentil and sesame plants at three different growth stages.

\section{MATERIALS AND METHODS}

Rhizosphere sampling. Lentil (Lens culinaris Medik.) and sesame (Sesamum indicum L.) seeds were cultivated at the Botanical Garden of Botany Department, Faculty of Science, Assiut University. Roots of these plants were gently removed with superfluous soil layer at three different growth stages (stage I after 7 days, stage II after 45 days and stage III after 75 days from cultivation). The rhizosphere soils were 
placed in clean polyethylene plastic bags and transferred to laboratory for determining rhizosphere fungi.

Rhizoplane sampling. From the same plants and at the same stages, roots of lentil and sesame were collected as well as uprooted, dislodged from the adhering soil and directly transferred into clean polyethylene plastic bags and transferred to laboratory for determining rhizoplane fungi.

Isolation of rhizosphere Fusarium and other fungi of lentil and sesame plants. This group of fungi was isolated using the dilution-plate and soil-plate methods.

Dilution-plate method. The dilution-plate method was used to determine Fusarium and other fungi in soil as described by Johnson et al. (1959) and as employed in this laboratory by Moubasher and Abdel-Hafez (1978a, b) and could be summarized as follows:

1- Two g of roots with adhering soil particles were placed in weighed flask that contained $100 \mathrm{ml}$ of sterile distilled water, thoroughly shaking for about 5 minutes.

2- One $\mathrm{ml}$ of the suitable rhizosphere soil suspension was transferred to each sterile Petri-dish and covered with melted but cooled dichloran chloramphenicol peptone agar (DCPA) (Andrews, Pitt 1986). For every rhizosphere sample, 5 agar plates were used. The plates were incubated at $25^{\circ} \mathrm{C}$ for $7-10$ days and the developing fungi were counted, isolated and identified. The counts were calculated as colony forming units (CFU) per g of rhizosphere soil. The number of colonies for each fungus in each plate was multiplied by the dilution factor to obtain the number per $\mathrm{g}$ in the original soil sample, and then the average per 5 plates was calculated.

Soil-plate method. Soil-plate method adopted from Warcup (1950) was used to isolate rhizosphere fungi. Adhering or associated soil particles to the roots of tested plants were removed and $0.2 \mathrm{~g}$ of soil particles were transferred into the surface of each of DCPA agar plates. The plates were incubated at $25^{\circ} \mathrm{C}$ for $7-10$ days. The developing fungi were counted, isolated, identified and thereafter calculated as $\mathrm{CFU}$ per g of dry soil.

Isolation of rhizoplane Fusaria and other fungi of lentil and sesame plants. The estimation of these fungi was carried out as practicised by Abdel-Hafez et al. (1990). The roots of plants were subjected to a series of washing with sterile distilled water. They were thoroughly dried between sterile filter papers, cut into segments (each about $1 \mathrm{~cm}$ ) and 25 of these segments ( 5 per plate) were put on the surface of 5 DCPA agar plates. The plates were incubated at $25^{\circ} \mathrm{C}$ for 7 days and the developing colonies were counted, isolated and identified. The fungal counts were expressed as CFU per 25 segments of fresh roots.

Medium used for isolation of Fusarium species. Dichloran chloramphenicol peptone agar (DCPA) which was developed for selective isolation of Fusarium species and dematiaceous hyphomycetes from cereals by Andrews and Pitt (1986) was used. Medium contains per liter of distilled water: peptone, $15 \mathrm{~g}$; $\mathrm{KH}_{2} \mathrm{PO}_{4}, 1 \mathrm{~g}$; $\mathrm{MgSO}_{4} .7 \mathrm{H}_{2} \mathrm{O}, 0.5 \mathrm{~g}$; dichloran $(0.2 \%$ solution in ethanol), $1 \mathrm{ml}$; chloramphenicol, $0.2 \mathrm{mg}$; agar, $15 \mathrm{~g}$. The medium was sterilized at $121^{\circ} \mathrm{C}$ for $15 \mathrm{~min}$; the final $\mathrm{pH}$ was 6.2 . 


\section{RESULTS}

Fusarium species and other fungi associated with rhizosphere soil of lentil plants. Nine Fusarium species and ten genera of other fungi were identified from isolates of the three tested growth stages (stage I after $7 \mathrm{~d}$, stage II after $45 \mathrm{~d}$ and stage III after $75 \mathrm{~d}$ from cultivation) using the dilution-plate and soil-plate methods (Tab. 1).

The dilution-plate method revealed recovery of Fusarium CFU, that accounted at $33.33,62.07$ and $38.71 \%$ of total fungi taxa in the three stages, respectively, and the highest count was obtained in stage II. Seven species in addition to some unidentified species of Fusarium were recorded from the three tested growth stages (Tab. 2). Fusarium solani was isolated from the every growth stage. F. culmorum and $F$. tricinctum were isolated from two growth stages while $F$. chlamydosporum, $F$. lateritium, F. nygamai and $F$. sporotrichioides were isolated from single growth stage.

Table 1

Summarized data showing the source of isolation of the pathogens

\begin{tabular}{|c|c|c|c|c|}
\hline \multirow[t]{2}{*}{ Species recorded } & \multicolumn{2}{|c|}{ Lentil } & \multicolumn{2}{|c|}{ Sesame } \\
\hline & $\begin{array}{l}\text { Rhizos- } \\
\text { phere }\end{array}$ & $\begin{array}{l}\text { Rhizo- } \\
\text { plane }\end{array}$ & $\begin{array}{l}\text { Rhizos- } \\
\text { phere }\end{array}$ & $\begin{array}{l}\text { Rhizo- } \\
\text { plane }\end{array}$ \\
\hline \multicolumn{5}{|l|}{ Fusarium Link } \\
\hline F. acutatum Ellis \& Everhart & & & + & \\
\hline F. chlamydosporum Wollenweber \& Reinking & + & & & + \\
\hline F. culmorum (W.G. Smith) Saccardo & + & + & & \\
\hline F. lateritium Nees & + & + & & \\
\hline F. longipes Wollenweber \& Reinking & & & & + \\
\hline F. nygamai Burgess \& Trimboli & + & + & + & \\
\hline F. oxysporum Schlechtendal emend. Snyder \& Hansen & + & + & + & + \\
\hline F. poae (Peck) Wollenweber & & & + & + \\
\hline F. sambucinum Fuckel & & & + & \\
\hline F. semitectum Berkeley \& Ravenel & & & + & \\
\hline F. solani (Martius) Appel \& Wollenweber & + & + & + & + \\
\hline F. sporotrichioides Sherbakoff & + & & & \\
\hline $\begin{array}{l}\text { F. subglutinans (Wollenweber \& Reinking) Nelson, } \\
\text { Toussoum \& Marasas }\end{array}$ & & + & & \\
\hline F. tricinctum (Corda) Saccardo & + & & + & \\
\hline F. udum Butler & & + & & \\
\hline F. verticillioides (Saccardo) Nirenberg & + & + & + & + \\
\hline Fusarium spp. & + & + & + & + \\
\hline \multicolumn{5}{|l|}{ Other fungi } \\
\hline Acremonium sp. & + & & + & \\
\hline Alternaria sp. & & + & + & \\
\hline Aspergillus spp. & + & + & + & + \\
\hline Cladosporium spp. & + & & + & \\
\hline Gliocladium sp. & & & + & \\
\hline Myrothecium sp. & & & + & \\
\hline Penicillium spp. & + & + & + & + \\
\hline Phoma spp. & + & & & \\
\hline Scopulariopsis spp. & + & & + & \\
\hline Setosphaeria spp. & + & & + & + \\
\hline Stachybotrys spp. & + & + & + & \\
\hline Stemphylium sp. & + & & & \\
\hline Trichurus sp. & + & & & \\
\hline Ulocladium sp. & & & + & \\
\hline
\end{tabular}


,

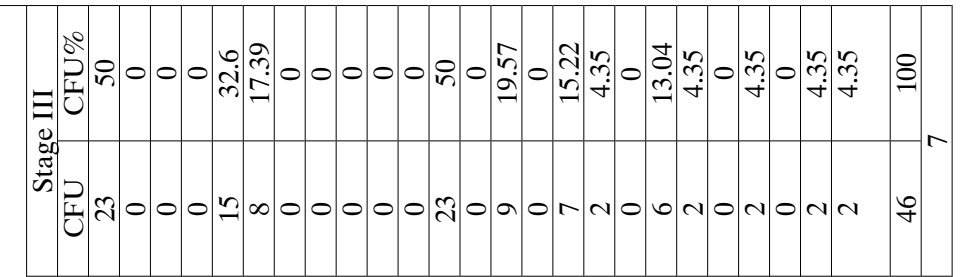

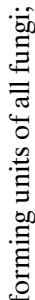

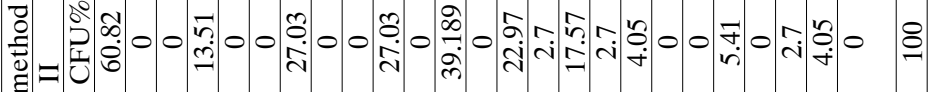

$\frac{3}{8}$

亲

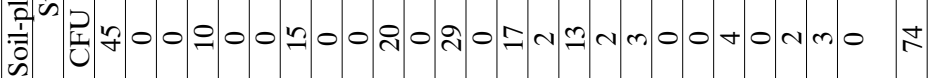

풍

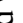

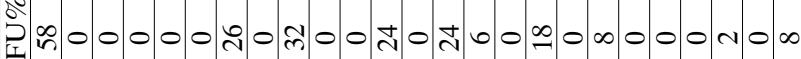

§ 品

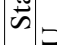

丕

(20)

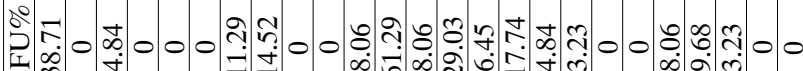
$\exists$ 无全

离.

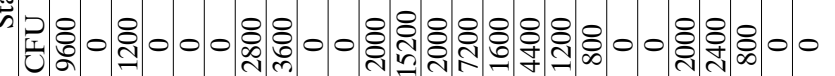

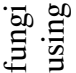

它

징

10

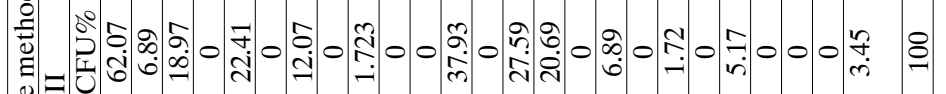

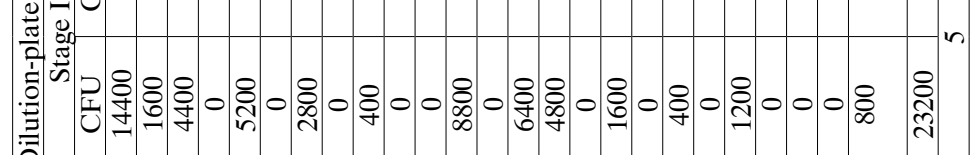

西

की

泀

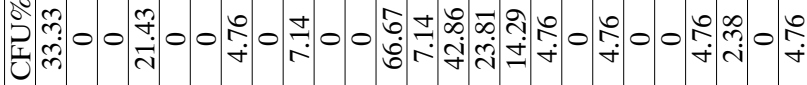

帘

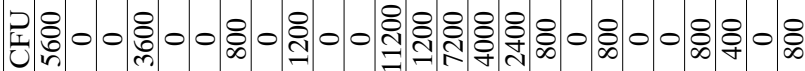


Other eight fungal genera were also recorded with Aspergillus P. Micheli ex Link as the only taxon isolated in all growth stages.

The soil-plate method resulted in recovering Fusarium from the three tested growth stages, constituting 58, 60.82 and $23 \%$ of total fungi CFU, respectively and the highest count was obtained in stage II. Six species of Fusarium were recorded (Tab. 2). Single species, F. solani, was isolated from two growth stages of lentil plants while the remaining five $F$. lateritium, F. nygamai, F. oxysporum, F. tricinctum and $F$. verticillioides were isolated from one growth stage of lentil plants (Tab. 2).

Other nine fungal genera were also recorded with Aspergillus as the only taxon isolated in all growth stages. Species of Penicillium Link, Stachybotrys Corda, Stemphylium Wallroth and Trichurus Clem. were isolated from two growth stages of lentil plants (Tab. 2).

Fusarium species and other fungi associated with rhizoplane of lentil plants. Fusarium fungi were isolated frequently from the plants in all three growth stages. They constituted 82.86, 58.97 and $72.09 \%$ of total fungi CFU, respectively. Eight species in addition to some unidentified species of Fusarium were recorded at the three growth stages (Tabs 1, 3). F. solani was isolated from the three growth stages of lentil plants. F. nygamai and $F$. verticillioides were recorded in two growth stages whereas $F$. culmorum, F. lateritium and $F$. oxysporum were recorded in only the first growth stage and F. subglutinans and $F$. udum in only the third stage (Tab. 3).

Other four fungal genera were recorded at different growth stages of which $A s$ pergillus fungi were isolated in all stages.

Fusarium species and other fungi associated with rhizosphere of sesame plants. Nine Fusarium species and eleven genera of other fungi were isolated from the three

Table 3

Colony forming units of Fusarium species and other fungi taxa associated with rhizoplane of lentil plants at three growth stages

\begin{tabular}{|l|c|c|c|c|c|c|}
\hline \multirow{2}{*}{ Taxa } & \multicolumn{2}{|c|}{ Stage I } & \multicolumn{2}{c|}{ Stage II } & \multicolumn{2}{c|}{ Stage III } \\
\cline { 2 - 7 } & CFU & CFU\% & CFU & CFU\% & CFU & CFU\% \\
\hline Fusarium (total) & 29 & 82.86 & 23 & 58.97 & 31 & 72.09 \\
\hline F. culmorum & 7 & 20 & 0 & 0 & 0 & 0 \\
\hline F. lateritium & 2 & 5.71 & 0 & 0 & 0 & 0 \\
\hline F. nygamai & 2 & 5.71 & 0 & 0 & 3 & 6.98 \\
\hline F. oxysporum & 1 & 2.86 & 0 & 0 & 0 & 0 \\
\hline F. solani & 17 & 48.57 & 15 & 38.46 & 7 & 16.28 \\
\hline F. subglutinans & 0 & 0 & 0 & 0 & 2 & 4.65 \\
\hline F. udum & 0 & 0 & 0 & 0 & 8 & 18.6 \\
\hline F. verticillioides & 0 & 0 & 7 & 17.95 & 11 & 25.58 \\
\hline Fusarium sp. & 0 & 0 & 1 & 2.56 & 0 & 0 \\
\hline Other fungi (total) & 6 & 17.14 & 16 & 41.03 & 12 & 27.91 \\
\hline Alternaria spp. & 0 & 0 & 3 & 7.69 & 0 & 0 \\
\hline Aspergillus (total) & 3 & 8.57 & 5 & 12.82 & 9 & 20.93 \\
\hline A. ochraceus Wilhelm & 2 & 5.71 & 3 & 7.69 & 5 & 11.63 \\
\hline Aspergillus spp. & 1 & 2.86 & 2 & 5.13 & 4 & 9.3 \\
\hline Penicillium spp. & 3 & 8.57 & 6 & 15.38 & 0 & 0 \\
\hline Stachybotrys spp. & 0 & 0 & 2 & 5.13 & 3 & 6.98 \\
\hline Total & 35 & 100 & 39 & 100 & 43 & 100 \\
\hline No. of genera & & 3 & & 5 & & 3 \\
\hline
\end{tabular}

Abbreviations: CFU: Colony forming units (out of 25 lentil root segments); CFU\%: calculated per total colony forming units of all fungi; Stage I: after 7 days, Stage II: $45 \mathrm{~d}$, Stage III: $75 \mathrm{~d}$ from a cultivation. 


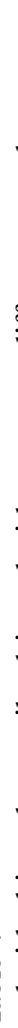

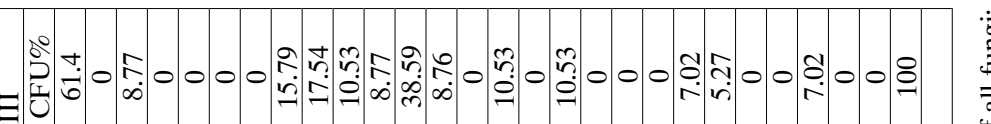

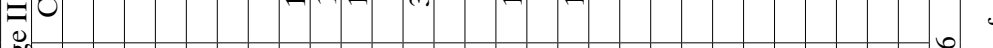

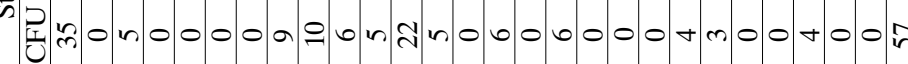

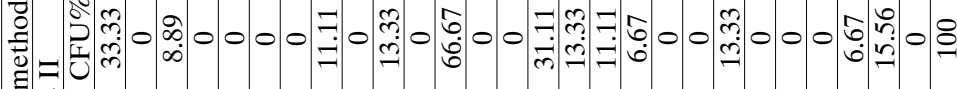
至

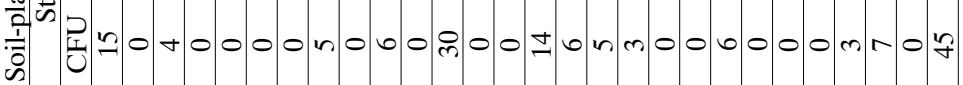

至

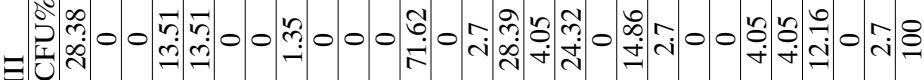

\section{.}

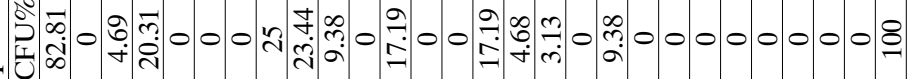

离

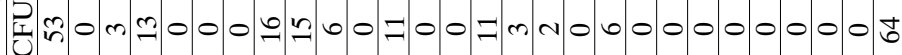

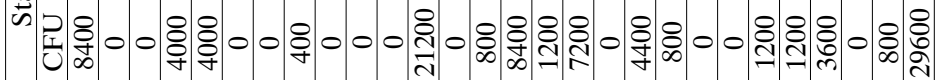

(1)

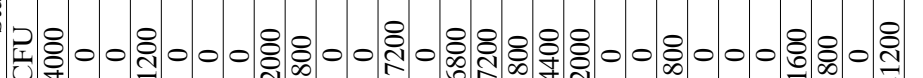

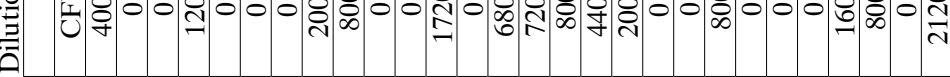

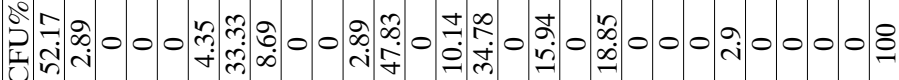
品

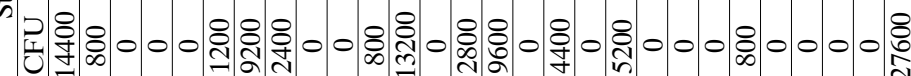


growth stages investigated of sesame plants using the dilution-plate and soil-plate methods (Tabs 4, 5).

The dilution-plate method revealed the discovery of Fusarium from the three tested growth stages, constituting $52.17,18.87$ and $28.38 \%$ of total fungi in the three stages, respectively. The highest count was obtained in stage I (Tab. 4). Seven species in addition to some unidentified species of Fusarium were recorded from rhizosphere soil at the three tested growth stages. F. solani was isolated from the three growth stages with its best count being found in stage I. F. oxysporum was isolated from two growth stages only. F. acutatum, F. poae, F. sambucinum, F, semitectum and F. tricinctum were isolated from one growth stage.

Other nine fungal genera were also recorded on this medium from the tested growth stages. Among them Aspergillus and Alternaria Nees were isolated from all growth stages.

The soil-plate method resulted in recovery of Fusarium from the three tested growth stages which constituted $82.81,33.33$ and $61.4 \%$ of total fungi CFU in the three stages, respectively with the highest count in stage I. Five species in addition to some unidentified species of Fusarium were recorded (Tab. 4). F. nygamai, F. solani and $F$. verticillioides were isolated from the three growth stages of sesame plants. $F$. tricinctum was isolated from two growth stages while $F$. oxysporum was isolated only from one growth stage, comprising high percentages of total CFU.

Other six fungal genera were also recorded from the tested growth stages of which Aspergillus was isolated in all growth stages. Gliocladium Corda and Setosphaeria Leonard \& Suggs were isolated from two growth stages.

Fusarium species and other fungi associated with rhizoplane of sesame plants. Fusarium was isolated from the rhizoplane of the three stages of sesame plant, comprising $76.67,85.71$ and $53.85 \%$ of total fungi, respectively. Its count varied between

Table 5

Colony forming units of Fusarium species and other fungi associated with rhizoplane of sesame plant at three different growth stages

\begin{tabular}{|l|c|c|c|c|c|c|}
\hline \multirow{2}{*}{ Taxa } & \multicolumn{2}{|c|}{ Stage I } & \multicolumn{2}{c|}{ Stage II } & \multicolumn{2}{c|}{ Stage III } \\
\cline { 2 - 7 } & CFU & CFU\% & CFU & CFU\% & CFU & CFU\% \\
\hline Fusarium (total) & 23 & 76.67 & 24 & 85.71 & 21 & 53.85 \\
\hline F. chlamydosporum & 15 & 50 & 0 & 0 & 0 & 0 \\
\hline F. longipes & 0 & 0 & 5 & 17.86 & 0 & 0 \\
\hline F. oxysporum & 0 & 0 & 0 & 0 & 13 & 33.33 \\
\hline F. poae & 3 & 10 & 0 & 0 & 2 & 5.13 \\
\hline F. solani & 3 & 10 & 15 & 53.57 & 6 & 15.38 \\
\hline F. verticillioides & 2 & 6.67 & 0 & 0 & 0 & 0 \\
\hline Fusarium spp. & 0 & 0 & 4 & 14.29 & 0 & 0 \\
\hline Other fungi (total) & 7 & 23.33 & 4 & 14.29 & 18 & 46.15 \\
\hline Aspergillus (total) & 7 & 23.33 & 4 & 14.29 & 9 & 23.08 \\
\hline A. flavus & 3 & 10 & 1 & 3.57 & 2 & 5.13 \\
\hline A. niger & 4 & 13.33 & 1 & 3.57 & 7 & 17.95 \\
\hline Aspergillus spp. & 0 & 0 & 2 & 7.15 & 0 & 0 \\
\hline Penicillium spp. & 0 & 0 & 0 & 0 & 4 & 10.25 \\
\hline Setosphaeria spp. & 0 & 0 & 0 & 0 & 5 & 12.82 \\
\hline Total & 30 & 100 & 28 & 100 & 39 & 100 \\
\hline No. of genera & & & & 2 & & 4 \\
\hline
\end{tabular}

Abbreviations. CFU: Colony forming units (out of 25 sesame root segments); CFU\%: calculated per total colony forming units of all fungi. Stage I: after 7 days, Stage II: $45 \mathrm{~d}$, Stage III: 75 d from a cultivation. 
21-24 CFU/25 sesame root segments and the highest count was obtained in stage II. Six species in addition to some unidentified species of Fusarium were recorded (Tab. 5). F. solani was recovered from the three stages with its highest CFU being found in stage II. F. poae was recorded in two growth stages, while $F$. chlamydosporum, F. longipes, $F$. oxysporum and $F$. verticillioides were recorded in one growth stage (Tab. 5).

Other three fungal genera were also recorded at the three growth stages and Aspergillus species was the most common.

\section{DISCUSSION}

\section{Fusarium species associated with rhizosphere and rhizoplane of lentil and sesame} plants. Fusarium species were found associated with rhizosphere and rhizoplane during the three growth stages of lentil and sesame plants (stage I after $7 \mathrm{~d}$, stage II after $45 \mathrm{~d}$ and stage III after $75 \mathrm{~d}$ from cultivation). The previous investigations achieved in this laboratory presented a good evidence that Fusarium is one of the basic constituents of fungi in the rhizosphere and rhizoplane of many Egyptian plants (Abdel-Fattah et al. 1977; Moubasher, Abdel-Hafez 1978a, b; El-Hissy et al. 1980; Moubasher et al. 1984; Mazen et al. 1982, 1991; Moubasher 1993; Abdel-Hafez et al. 1990, 1995; Hasan 2002; Al-Khateeb 2004; Gherbawy et al. 2006; Seddek 2007; Abdel-Hafez et al. 2009; Ismail et al. 2009). Many species of Fusarium e.g., F. acuminatum, F. avenaceum (Fries) Saccardo, F. culmorum, F. equiseti, F. oxysporum, F. sambucinum, F. solani, F. verticillioides and unidentified Fusarium spp. were isolated from lentil seeds in Saudi Arabia (Abdel-Hafez 1984), U.S. Pacific Northwest (Kaiser 1992) and Pakistan (Hussain et al. 2007; Rahim et al. 2010).

In total, 16 species of Fusarium were identified from rhizosphere (12 species using the dilution-plate and soil-plate methods), and rhizoplane (11 species using segment-plate method) of the two tested plants. F. solani was revealed in the three stages of both plants and its best count (CFU) was recorded during stage I or II. $F$. oxysporum was infrequently recovered from the three growth stages of the two investigated plants. In this respect, Li et al. (2012) isolated F. oxysporum, F. solani, $F$. proliferatum (Matsushima) Nirenberg and other 2 unidentified species from wilted sesame plants in China. In the studies of Fletcher et al. (1991) in New Zealand Fusarium avenaceum was reported as a major cause of collar rot and root rot of lentil while F. oxysporum, F. culmorum and F. acuminatum evoked disease symptoms but to a lesser extent than $F$. avenaceum. The last species influence was studied by Hwang et al. (2000) in Western Canada.

The remaining Fusarium species were encountered only from one or two stages. Some of these species were also recovered from the rhizophere and rhizoplane of some cultivated plants in Egypt such as cotton (Abdel-Hafez 1974), pea, tomato, maize and wheat seedlings (Moubasher et al. 1984), wheat (Abdel-Hafez et al. 1990, 2000) and sugarcane (Abdel- Hafez et al. 1995). Species of Fusarium and other fungal taxa reported earlier from Egypt as pathogens of lentil or sesame are shown in Table 6 . 
Several of the isolated species are also well-known as pathogenic to other numerous cultivated plants in Egypt (Abdel-Razik et al. 1976; Hussein et al. 1977; Abdel-Kader et al. 1978; Higgy et al. 1978; Rushdi et al. 1980, 1981; Mohamed et al. 1981, 1982; El-Mohamedy 2004; El-Mohamedy et al. 2006; El-Bramawy 2006; El-Bramawy, Shaban 2007).

It is meaningful that some species were recorded only from the rhizosphere $(F$. acutatum, $F$. sambucinum, $F$. semitectum), rhizoplane of sesame plants (F. longipes) or both (F. poae), while others only on lentil plants from the rhizosphere (F. sporotrichioides), rhizoplane (F. subglutinans, F. udum) or both (F. culmorum and F. lateritium). It is also worthy to mention that $F$. acutatum is being recorded for the first time in Egypt from the rhizosphere and, F. longipes - from the rhizoplane of sesame plants, and $F$. nygamai - from the rhizosphere of lentil and sesame and rhizoplane of lentil plants.

Fungi other than Fusarium were also reported e.g., Aspergillus and Penicillium were commonly isolated from the rhizosphere and rhizoplane of both plants while others were reported only from one plant or from only rhizosphere or rhizoplane of one or both plants (Tab. 1). To this group of fungi belong Alternaria, Cladosporium and Stemphylium are among referred to as the pathogens of lentil (Kaiser 1981). Stemphylium botryosum was reported to cause Stemphylium blight of lentil in many parts of the world including Egypt (Bayaa, Erskine 1998; Rahman et al. 2010). Those and other fungi taxa, namely member of Alternaria, Aspergillus (A. niger, A. flavus, $A$. terreus Thom), Botrytis Micheli, Chaetomium Kunze, Macrophomina phaseolina, $M u$ cor Fresenius, Nigrospora Zimmermann, Penicillium, Phoma (Fries) Desmazieres, Rhizopus Ehrenb., Rhizoctonia solani, Stemphylium and Trichoderma Persoon were also isolated from lentil seeds in U.S. Pacific Northwest (Kaiser 1992) and Pakistan (Hussain et al. 2007; Rahim et al. 2010). The short literature survey of the pathogens recorded previously from lentil and sesame in Egypt is presented in Table 6.

Table 6

Fungal species reported from Egypt as lentil and sesame pathogens by other authors

\begin{tabular}{|c|c|c|c|}
\hline Plant & Fungal species & $\begin{array}{c}\text { Disease/ } \\
\text { Source }\end{array}$ & References \\
\hline \multirow[t]{3}{*}{ Lentil } & $\begin{array}{l}\text { Fusarium oxysporum Schlechtendal } \\
\text { emend Snyder \& Hansen f. sp. lentis } \\
\text { Vasudeva \& Srinivasan }\end{array}$ & Wilt & $\begin{array}{l}\text { Morsy 2005; Sallam, Abdel-Monaim } \\
2012\end{array}$ \\
\hline & Stemphylium botryosum Wallroth & $\begin{array}{l}\text { Stemphylium } \\
\text { blight }\end{array}$ & Bayaa, Erskine 1998 \\
\hline & $\begin{array}{l}\text { Aspergillus fumigatus Fresenius, } A \text {. } \\
\text { niger, } \text { A. flavus, A. terreus, Penicillium } \\
\text { notatum Westling and Rhizopus } \\
\text { oryzae Went \& Prinsen-Geerligs }\end{array}$ & Seeds & El-Maraghy 1988 \\
\hline \multirow[t]{5}{*}{ Sesame } & $\begin{array}{l}\text { Aspergillus flavipes (Bainier \& } \\
\text { Sartory) Thom \& Church }\end{array}$ & Rhizoplane & \multirow[t]{2}{*}{ Hasan 2002} \\
\hline & $\begin{array}{l}\text { Aspergillus flavus, } A \text {. niger, } \\
\text { Fusarium oxysporum, Rhizopus } \\
\text { stolonifer (Ehrenberg) Vuillemin }\end{array}$ & $\begin{array}{l}\text { Rhizoplane } \\
\text { and } \\
\text { rhizosphere }\end{array}$ & \\
\hline & F. oxysporum f. sp. sesame (Zap.) Cast & Wilt & $\begin{array}{l}\text { Ziedan 1993, 1998; Khalifa 1997, } \\
\text { Sahab et al. 2001; El-Bramawy, } \\
\text { Abdel-Wahid 2007, 2009; Ziedan et } \\
\text { al. } 2012\end{array}$ \\
\hline & $\begin{array}{l}\text { Macrophomina phaseolina (Tassi) } \\
\text { Goidanich }\end{array}$ & $\begin{array}{l}\text { Charcoal rot } \\
\text { disease }\end{array}$ & $\begin{array}{l}\text { El-Fiki et al. 2004; El-Bramawy, } \\
\text { Abdel-Wahid } 2007\end{array}$ \\
\hline & Rhizoctonia solani Kühn & Root rot & El-Bramawy, Abdel-Wahid 2007 \\
\hline
\end{tabular}




\section{CONCLUSIONS}

Of the sixteen Fusarium species isolated during the current investigation, only three, namely $F$. oxysporum, $F$. solani and $F$. verticillioides were recorded, from the rhizosphere and rhizoplane of both plants. However, only $F$. solani was recorded at the three stages of both plants. Of the species recorded, some are known as pathogenic to both plant species, and others are recorded for the first time from lentil or sesame in Egypt. Of fungi other than Fusarium, only Aspergillus and Penicillium species were recorded from both rhizosphere and rhizoplane of both plants.

\section{REFERENCES}

Abdel-Fattah H.M., Moubasher A.H., Abdel-Hafez S.I. 1977. Fungus flora of root and leaf surface of broad bean cultivated in Oases, Egypt. Naturalia Monspeliensis, Ser. Bot. 27: 167-177.

Abdel-Hafez S.I.I. 1974. Ecological studies on Egyptian soil fungi. Ph. D. Thesis. Department of Botany, Faculty of Science, Assiut University, Egypt.

Abdel Hafez S.I.I. 1984. Mycoflora of bean, broad bean, lentil, lupine and pea seeds in Saudi Arabia. Mycopathologia 88(1): 45-49.

Abdel-Hafez S.I., Mazen M.B., Shaban G.M. 1990. Seasonal fluctuation of rhizosphere and rhizoplane fungi of Egyptian wheat plant. Bulletin of the Faculty of Science, Assiut University, Egypt 19 (1-D): $173-184$.

Abdel-Hafez S.I.I., El-Said A.H.M., Gherbawy Y.A.M.H. 1995. Seasonal fluctuation of soil and root surface fungi of sugarcane (Saccharum officinarum L.) in Egypt. Bulletin of the Faculty of Science, Assiut University, Egypt 24 (2-D): 131-151.

Abdel-Hafez S.I.I., Moharram A.M., Abdel-Sater M.A. 2000. Monthly variations in the mycobiota of wheat fields in El-Kharga Oasis, Western Desert, Egypt. Bulletin of the Faculty of Science, Assiut University, Egypt 29 (2-D): 195-211.

Abdel-Hafez S.I.I., Ismail M.A., Hussein N.A., Nafady N.A. 2009. The diversity of Fusarium species in Egyptian soils, with three new record species. The first International Conference of Biological Sciences, March 4-5th 2009, Faculty of Science, Assiut University, Assiut, Egypt. Assiut University Journal of Botany (Special Publication No. 1): 129-147.

Abdel-Kader M.I.A., Moubasher A.H., Abdel-Hafez S.I.I. 1978. Selective effects of five pesticides on soil and cotton-rhizosphere and rhizoplane fungus flora. Mycopathologia 66: 117-123.

Abdel-Razik A., Darweish F., Rushdi M., Abd-El-Kader A. 1976. Role of polysaccharides in pathogenesis of fungi inciting damping-off and root-rot of lentil. Assiut Journal of Agricultural Science 7 (3): $15-24$.

Al-Khateeb W.A.M. 2004. Some mycological, phytopathological and physiological studies on mycobiota of selected newly reclaimed soils in Assiut Governorate, Egypt. M.Sc. Thesis, Department of Botany, Faculty of Science, Assiut University, Egypt, 238 pp.

Andrews S., Pitt J.I. 1986. Selective medium for isolation of Fusarium species and dematiaceous Hyphomycetes from cereals. Applied and Environmental Microbiology 51 (6): 1235-1238.

Bhatty R.S. 1988. Composition and quality of lentil (Lens culinaris Medik.): a review. Canadian Institute of Food Science and Technology Journal 21 (2): 144-160.

Bayaa B., Erskine W. 1998. Diseases of lentil. (In:) The Pathology of Food and Pasture legumes. Allen D.J. and Lenne, J.M. (eds). CAB International, Wallingford, United Kingdom, 786 pp.

Campbell C.L., Neher D.A. 1996. Principles and practice of managing soilborne plant pathogens, APS Press, St. Paul, MN, pp. 20-49.

Davey C.B., Papavizas G.C. 1960. Effect of decomposing organic soil amendments and nitrogen on fungi in soil and bean rhizosphere. Trans. Intern. Cong. Soil Sci. 7th Cong. (Madison Wisc.) Comm. 111: 551-557.

El-Bramawy M.A.S. 2006. Inheritance of resistance to Fusarium wilt in some sesame crosses under field conditions. Plant Protection Science 42 (3): 99-105. 
El-Bramawy M.A.S., Abdel-Wahid O.A. 2007. Identification of genetic resources for resistance to Fusarium wilt, charcoal root rot and Rhizoctonia root rot among sesame (Sesamum indicum L.) germplasm. African Crop Science Conference Proceedings 8: 1893-1900.

El-Bramawy M.A.S., Shaban W.I. 2007. Nature of gene action for yield, yield components and major diseases resistance in sesame (Sesamum indicum L.). Research Journal of Agriculture and Biological Sciences 3 (6): 821-826.

El-Bramawy M.A.S.A., Abdel-Wahid O.A. 2009. Evaluation of resistance of selected sesame (Sesamum indicum) genotypes to Fusarium wilt disease caused by Fusarium oxysporum f.sp. sesami. Tunisian Journal of Plant Protection 4 (1): 29-39.

El-Fiki A.I.I., Mohamed F.G, El-Deeb A.A., Khalifa M.M.A. 2004. Some applicable methods for controlling sesame charcoal rot disease (Macrophomina phaseolina) under greenhouse conditions. Egyptian Journal of Phytopathology 32 (1-2): 87-101.

El-Maraghy S.S.M. 1988. Aflatoxins and fungal flora in lentil (Lens esculenta L.). Mycopathologia 102 (1): 31-35.

El-Hissy F.T., Abdel-Hafez S.I., Abdel-Kader M.I. 1980. Rhizosphere fungi of five plants in Egypt. Zeitschrift fur Allgemeine Mikrobiologie 20 (3): 177-184.

El-Mohamedy R.S.R. 2004. Control of Fusarium root rot disease on mandarin by soil amendment with Trichoderma harzianum grown on bagasse. Journal of Agricultural Sciences, Mansoura University, Egypt 29 (1): 83-95.

El-Mohamedy R.S.R., Abd Alla M.A., Badiaa R.I. 2006. Soil amendment and seed bio-priming treatments as alternative fungicides for controlling root rot diseases on cowpea plants in Nobaria Province. Research Journal of Agriculture and Biological Science 2 (6): 391-398.

Fletcher J.D., Broadhurst P.G., Bansal R.K.1991. Fusarium avenaceum: A pathogen of lentil in New Zealand. New Zealand Journal of Crop and Horticultural Science 19 (2): 207-210.

Foster R.C. 1986. The ultrastructure of rhizoplane and rhizosphere. Annual Review of Phytopathology 24: 211-234.

Gherbawy Y., Maghraby T., Yassmin S. 2006. Seasonal variation of Fusarium species in wheat fields in Upper Egypt. Phytopathology and Plant Protection 39 (5): 365-377.

Hamdi A.; Omar S.A., Amer M.I. 1991. Production of high yielding lines of lentil with resistance to rootrot / wilt disease complex. Egyptian Journal of Applied Sciences 6 (4): 18-29.

Hasan H.A.H. 2002. Gibberellin and auxin production by plant root-fungi and their biosynthesis under salinity-calcium interaction. Rostlinná Výroba 48 (3): 101-106.

Higgy A.H., Abd-Elrazik A.A., Rushdi M.H. 1978. Occurrence of pokkah boeng disease of sugarcane in ARE. Plant Pathology 1: 473-481.

Hussain M.A., Mukhtar T., Irfan ul-Haque M., Kayani M.Z. 2007. Mycoflora associated with lentil (Lens esculenta Moench) seeds from five localities of Punjab, Pakistan. Pakistan Journal of Botany 39 (3): 903-906.

Hussein F.N., Abd-Elrazik A., Darweish F.A., Rushdi M.H. 1977. Survey of storage diseases of onions and their incidents in Upper Egypt. Journal of Phytopathology 9: 15-21.

Hwang S.F., Gossen B.D., Turnbull G.D., Chang K.F., Howard R.J., Thomas A.G. 2000. Effect of temperature, seeding date, fungicide seed treatment and inoculation with Fusarium avenaceum on seedling survival, root rot severity and yield of lentil. Canadian Journal of Plant Science 80: 899-907.

Ismail M.A., Abdel-Hafez S.I.I., Hussein N.A., Nafady N.A. 2009. Monthly fluctuations of Fusarium species in cultivated soil, with a new record species. The first International Conference of Biological Sciences, March 4-5th 2009, Faculty of Science, Assiut University, Assiut, Egypt. Assiut University Journal of Botany (Special Publication No. 1): 117-128.

Johnson L.F., Curl E A., Bond J.H., Fribourg H.A. 1959. Methods for studying soil microflora-plant disease relationships. Minneapolis Publ. 178 pp.

Kaiser W.J. 1981. Diseases of chickpea, lentil, pigeon pea, and tepary bean in continental United States and Puerto Rico. Economic Botany 35 (3): 300-320.

Kaiser W.J. 1992. Fungi associated with the seeds of commercial lentils from the U.S. Pacific Northwest. Plant Disease 76: 605-610.

Katznelson H., Lochhead A.G., Timonin M.I. 1948. Soil microorganisms and the rhizosphere. Botanical Review 14: 543-587.

Khalifa M.M.A. 1997. Studies on root-rot and wilt diseases of sesame (Sesamum indicum L.). M. Sc. Thesis, Faculty of Agriculture, Zagazig University, Egypt, 158 pp. 
Kolte S.J. 1985. Diseases of annual edible oil seed crops. II: 221-232: 26-31. (In:) Rapeseed, Mustard, Safflower and Sesame diseases. CRC Press inc. Boca Raton, Florida, 316. pp.

Li D.H., Wang L.H., Zhang Y.X., Lv H.X., QI X.Q., Wei W.L., Zhang X.R. 2012. Pathogenic variation and molecular characterization of Fusarium species isolated from wilted sesame in China. African Journal of Microbiology Research 6 (1): 149-154.

Mandeel Q.A. 2002. Microfungal community associated with rhizosphere soil of Zygophyllum qatarense in arid habitats of Bahrain. Journal of Arid Environments 50: 665-681.

Mandeel Q., Baker R. 1991. Mechanisms involved in biological control of Fusarium wilt of cucumber with strains of nonpathogenic Fusarium oxysporum. Phytopathology 81 (4): 462-469.

Mazen M.B., Moubasher A.H., Abdel-Hafez A.I.I. 1982. Studies on the genus Fusarium in Egypt. IV. Seasonal fluctuations of air-borne fungi with special reference to Fusarium. Bulletin of the Faculty of Science, Assiut University, Egypt 11 (1): 95-103.

Mazen M.B., Moubasher A.H., Abdel-Hafez A.I.I. 1991. Ecological studies on the genus Fusarium in Egyptian soils. Bulletin of the Faculty of Science, Assiut University, Egypt 20 (1-D): 73-87.

Mohamed M.S., Sellam M.A., Abd-Alrazik A., Rushdi M.H. 1981. Effect of root exudates of different plants of certain crop rotations on the incitants of tomato damping-off and Fusarium basal rot of onion. Egyptian Journal of Phytopathology 13 (1-2): 41-50.

Mohamed M.S., Sellam M.A., Abd-Elrazik A., Rushdi M.H. 1982. Effect of crop rotation on tomato damping-off and onion basal rot as well on the populations of their mycopathogens and Bacillus subtilis in soil. Anzeiger Schadlingskde, Pflanzenschutz, Umweltschutz 55: 181-184.

Morsy K.M.M. 2005. Induced resistance against damping-off, root rot and wilt diseases of lentil. Egyptian Journal of Phytopathology 33: 53-63.

Moubasher A.H. 1993. Soil fungi of Qatar and other Arab countries. The Scientific and Applied Research Center, University of Qatar, Doha, Qatar, 566 pp.

Moubasher A.H., Abdel-Hafez S.I. 1978a. Study on the mycoflora of Egyptian soils. Mycopathologia 63 (1): $3-10$.

Moubasher A.H., Abdel-Hafez S.I. 1978b. Further study on seasonal fluctuations of Egyptian soil fungi. Mycopathologia 63 (1): 11-19.

Moubasher A.H., Mazen M.B., Abdel-Hafez A.I.I. 1984. Studies on the genus Fusarium in Egypt: Seasonal fluctuations of Fusarium in the rhizoplane of five plants. Mycopathologia 85 (3): 161-165.

Rahim S., Dawar S., Tariq M. 2010. Mycoflora associated with lentil (Lens culinaris L.) seeds of Pakistan. Pakistan Journal of Botany 42 (6): 4345-4352.

Rahman T., Ahmed A.U., Islam M.R., Hosen M.I. 2010. Physiological study and both in vitro and in vivo antifungal activities against Stemphylium botryosum causing Stemphylium blight disease in lentil (Lens culinaris). Plant Pathology Journal 9 (4): 179-187.

Rushdi M.H., Sellam M.A., Abd-Elrazik A., Allam A.D., Salem A. 1980. Histological changes induced by Meloidogyne javanaica and Fusarium species on roots of selected leguminous plants. Egyptian Journal of Phytopathology 12 (1-2): 43-47.

Rushdi M.H., Sellam M.A., Abd-Elrazik A., Allam A.D., Salem A. 1981. Physiological and biochemical changes in broadbean roots due to infection with Fusarium oxysporum, Meloidogyne javanica and their combination. Assiut Journal of Agriculture Science, Egypt 12 (1): 81-89.

Sahab A.F., Elewa I.S., Mostafa M.H., Ziedan E.H. 2001. Integrated control of wilt and root-rot diseases of sesame in Egypt. Egyptian Journal of Applied Sciences 16(7): 448-462.

Sallam N.M.A., Abdel-Monaim M.F. 2012. Influence of some agricultural practices on suppression of lentil wilt disease. Plant Pathology Journal 11(1): 32-37.

Schroth M.N., Hancock J.G. 1981. Disease-suppressive soil and root-colonizing bacteria. Science 216: 1376-1381.

Seddek N.H. 2007. Fungi associated with some wild plants. M. Sc. Thesis, Department of Botany, Faculty of Science, Assiut, University, Egypt, 258 pp.

Srivastava V.B., Mishra R.R. 1971. Investigations into rhizosphere microflora. I. Succession of microflora of root regions of Oryza sativa Linn. Microbiol Esp. 24 (3): 193-205.

Taylor P.K., Lindbeck W., Chen W., Ford R. 2007. Lentil diseases. (In:) S.S. Yadav, D. McNeil, P.C. Stevenson (eds). Lentil: An ancient crop for modern times. Springer, The Netherlands: 291-313.

Warcup J.H. 1950. Soil-steaming: a selective method for the isolation of Ascomycetes from soil. Transactions of the British Mycological Society 34: 515-532. 
Ziedan E.H.E. 1993. Studies on Fusarium wilt disease of sesame in Arabic Republic of Egypt. M. Sc. Thesis, Plant Pathology Department, Faculty of Agriculture, Ain-Shams University, Egypt, 121 pp.

Ziedan E.H.E. 1998. Integrated control of wilt and root-rot diseases of sesame in A.R.E. Ph.D. Thesis, Faculty of Agriculture, Ain-Shams University, Egypt, 169 pp.

Ziedan E.H., Mostafa M.H., Elewa I.S. 2012. Effect of bacterial inocula on Fusarium oxysporum f. sp. ses$a m i$ and their pathological potential on sesame. Journal of Agricultural Technology 8 (2): 699-709. 